Check for updates

Hurley Group, London

clare.gerada@nhs.net Follow Clare on Twitter: @ClareGerada Cite this as: $B M / 2021 ; 373: n 1312$ http://dx.doi.org/10.1136/bmj.n1312 Published: 25 May 2021

WOUNDED HEALER

\title{
Clare Gerada: Closing the gender wellbeing gap in medicine
}

\section{Clare Gerada GP partner}

Women from all walks of life and age groups have been disproportionately affected by the covid pandemic-especially regarding financial security, mental health, and additional care responsibilities. ${ }^{1-4}$ It's likely that female doctors are similarly affected. Over the years more women than men have presented to Practitioner Health, a confidential service for doctors with mental illness. ${ }^{5}$ This gender gap has widened over the past year: women now make up nearly $74 \%$ of new registrations, up from around $60 \%$ in October 2019, and their average age has dropped from 40 to 38 .

The BMA has been conducting surveys since the start of the pandemic. ${ }^{6}$ The responses have shown a disproportionate impact among female doctors compared with their male counterparts: they report higher levels of burnout, a poor state of wellbeing, fatigue, and unhealthy coping strategies, such as overeating or taking drugs.

The reasons for women being so affected are multifactorial, but they're almost certainly linked to the additional burdens of balancing an increasing workload with extra responsibilities and pressures at home. During lockdown these include extra time spent home schooling and the added constraints of covid related restrictions. Even shopping for food has taken longer, and more planning has been required. Women's unpaid domestic and care workloads have increased-arguably more so for younger women, as reflected in the lower average age of doctors presenting to Practitioner Health.

The usual support structures disappeared as nurseries closed and help from informal carers, such as grandparents, was unavailable for prolonged periods. Even when schools were open to key workers' children, the lack of after-school provision affected childcare arrangements. Where women receive help from partners and children, they actually provide much more time and care to those partners and children in return. ${ }^{37}$ And while childcare provisions are now returning to normal, the impact of this additional stress over the past year is still taking a toll on women's mental health.

Most doctors have seen an increased workload during the pandemic, exacerbated by staff shortages. BMA surveys highlight that this has fallen unevenly onto female doctors such that women feel more undue pressure to take on additional work-and $40 \%$ rarely or never take their breaks in full, compared with $28 \%$ of men. ${ }^{6}$

Women have come a long way in securing their rightful place in the medical workforce and now make up nearly half of it. Now is the time to redress the additional burdens placed on them-systemic barriers to career progression such as access to childcare, paid carers' leave, careers advice, and flexible working-and make real changes to accommodate their needs, rather than expecting women to continue risking their mental health.

Competing interests: See www.bmj.com/about-bmj/freelance-contributors.

Provenance and peer review: Commissioned; not externally peer reviewed.

Clare Gerada is chair of Doctors in Distress and medical director of NHS Practitioner Health. Her book, Beneath the White Coat: Doctors, their Minds and Mental Health, is published by Routledge and can be purchased at https://www.routledge.com/Beneath-the-White-Coat-Doctors-Their-Minds-andMental-Health/Gerada/p/book/9781138499737. All royalties will be donated to Doctors in Distress.

1 UN Women. The impact of COVID-19 on women's and men's lives and livelihoods in Europe and Central Asia. 17 Jul 2020. https://data.unwomen.org/publications/impact-covid-19-womens-and-mens-lives-and-livelihoods-europe-and-central-asia.

2 McKinsey \& Company. Women in the workplace. 2020. https://wiw-report.s3.amazonaws.com/Women_in_the_Workplace_2020.pdf.

3 Fawcett Society. Women are bearing the emotional brunt of the coronavirus crisis. 20 May 2020. https://www.fawcettsociety.org.uk/news/women-arebearing-the-emotional-brunt-of-the-coronavirus-crisis.

4 King's College, London. Life under lockdown: coronavirus in the UK. 9 Apr 2020. https://www.kcl.ac.uk/news/life-under-lockdown-coronavirus-in-theuk.

5 Gerada C, Jones R, Wessely A. Young female doctors, mental health, and the NHS working environment. BMJ 2014;348:g1doi: 10.1136/bmj.g1.

6 BMA. Personal impact of the Covid-19 pandemic on doctors' wellbeing revealed in major BMA survey. 1 Jun 2020. https://www.bma.org.uk/bmamedia-centre/personal-impact-of-the-covid-19-pandemic-on-doctorswellbeing-revealed-in-major-bma-survey.

$7 \quad$ United Nations. Shared responsibility, global solidarity: responding to the socio-economic impacts of COVID-19. Mar 2020 https://www.un.org/sites/un2.un.org/files/sg_report_socio-economic_impact_of_covid19.pdf. 